\title{
Humanitarian Engineering at The Ohio State University: Lessons Learned in Enriching Education While Helping People ${ }^{1}$
}

\author{
Gregory Bixler* \\ Engineering Education Innovation Center \\ The Ohio State University \\ bixler.17@osu.edu \\ Roger Dzwonczyk \\ Professor Emeritus \\ Engineering Education Innovation Center \\ The Ohio State University \\ dzwonczyk.1@osu.edu \\ John Merrill \\ Associate Director \\ Engineering Education Innovation Center \\ The Ohio State University \\ merrill.25@osu.edu
}

\author{
Joseph Campbell \\ Research Associate \\ School of Environmental and Natural Resources \\ and Knowlton School of Architecture \\ The Ohio State University \\ campbell.844@osu.edu \\ Howard L Greene \\ Senior Project Manager \\ COE Undergraduate Education \\ College of Engineering \\ The Ohio State University \\ greene.8@osu.edu \\ Kevin M Passino** \\ Professor, Electrical and Computer Engineering \\ Department Electrical and Computer Engineering \\ The Ohio State University \\ passino.1@osu.edu \\ ** Corresponding author
}

\begin{abstract}
Humanitarian engineering at The Ohio State University (OSU) has enriched our delivery of engineering education and at the same time led, via collaborative engagement, to helping people and communities. Here, we describe our curricular program, extracurricular activities, domestic and international projects, meetings and coordination, and our new Humanitarian Engineering Center. Throughout, we provide "lessons learned" for all these categories, and in conclusion provide some general lessons and challenges for engineering education.
\end{abstract}

Index - humanitarian engineering, service learning

\section{Introduction}

The problem of persistent poverty around the world is coincident with a number of factors including lack of access to clean water, sanitation, electricity, healthcare, education, etc. Additional key factors that complicate matters include a lack of technological capacity and good jobs. Most of these problems can be at least partially alleviated via engineering skills; hence there is a need to educate engineers at the undergraduate and graduate levels to collaboratively engage with communities locally and globally to meet these challenges. This is the goal of the humanitarian engineering program at OSU.

* Author names listed in alphabetical order rather than per order of contribution. 
OSU has been engaged in humanitarian engineering since at least 1979, but has had a vibrant and growing activity in this area that fully involves students since $2004^{2}$. In Autumn 2003 a faculty member started working with a student group to form a student organization Engineers for Community Service (ECOS). Local projects started immediately, and during Spring Break 2005 an engineering service project was completed at Montaña de Luz an orphanage in Honduras for children affected by HIV/AIDS. This led to the introduction of a service-learning course (see Section 2) to complete technical projects and prepare students for the trip each year since then. About 5 years later, other student organizations started to form (see Section 3), more international and local service projects were conducted (see Section 4), and more service-learning and capstone design courses were created to support the projects. In 2012 the Humanitarian Engineering Scholars (HES) program (a "living-learning community;" see Section 3) was established, followed by a general course on humanitarian engineering, and a Humanitarian Engineering Minor in 2014 (again, see Section 3). In summary, community service projects coupled with courses attracted significant student interest. This led to a significant expansion in service projects and courses to a range of countries involving many students. This led to the HES program and the minor. Our program grew bottom-up, from community needs and student interest, but of course under the significant involvement and leadership of faculty and staff. All of this led to the need for coordination (see Section 5), part of which is being achieved via the consolidation of our activities into a "Humanitarian Engineering Center" that was first formed in June 2014 (see Section 6).

After 10 years, a very active and well-functioning humanitarian engineering educational "ecosystem" has emerged (see Figure 1).

Financial sponsors

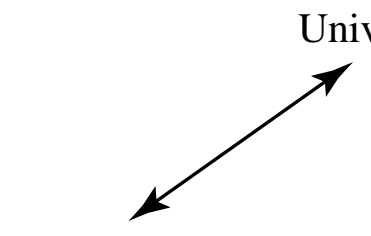
University partners/support

Faculty Staff

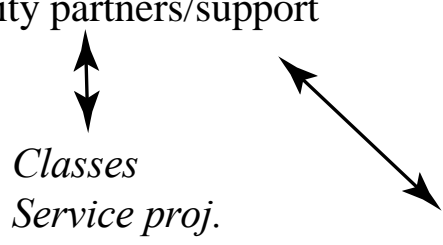
Service proj.
Minor
Research $\begin{aligned} & \text { Undergrad students } \\ & \text { Graduate students }\end{aligned}$
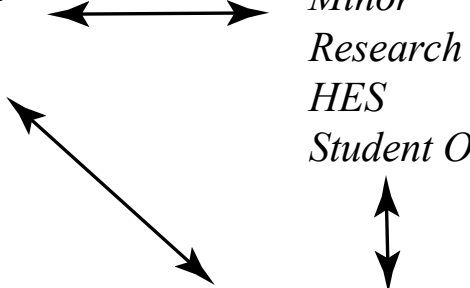

HES

Student Orgs.
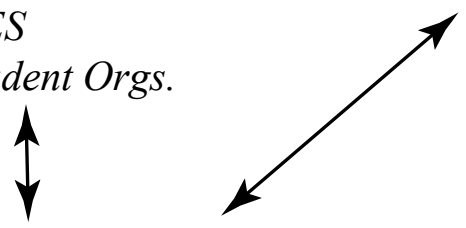

Partners and communities

(local and global)

FIGURE 1

OSU HUMANITARIAN ENGINEERING EDUCATIONAL “ECOSYSTEM.”

\footnotetext{
${ }^{2}$ For more information on the topics in this paper, please see: https://osuhe.engineering.osu.edu and in particular our history is outlined there.
} 
Figure 1 shows the people involved in our program around the perimeter of the diagram: undergraduate/graduate students, faculty/staff, partners/communities, financial sponsors, and university partners and support. The main interactions between the people are illustrated by the arrows, with the top part of the diagram showing university and university partner interactions, and the bottom part showing interactions with our community partners. Many of the interactions among the people in our program are facilitated by (mediated by) the activities in the center of the diagram in Figure 1 (in italics): classes, service projects, a minor, research, the HES program, and student organizations. These activities fall into two categories that we discuss next: curricular programs and extracurricular activities. This will be followed by an outline of our domestic and international projects, our coordination/meeting mechanisms, and a brief description of our Humanitarian Engineering Center.

\section{Curricular Programs}

Our curricular program is distributed with components that are college-based, and others that are department-based. It provides the educational background to do humanitarian engineering in a community, and provides credit for doing actual engineering service.

\section{Classes:}

Upon arriving at OSU, all engineering majors go through the "First Year Engineering Program." This is comprised of a two course series where topics in engineering fundamentals, including design-and-build projects, are covered. We have a specially designed 3-credit course for the freshmen in our HES program (see below):

ENGR 1181.02 Appropriate Technology Laboratory: HES's introduction to creating appropriate technology for developing countries. Students evaluate, research, and rank appropriate technology solutions. This theme is continued through course laboratories touching on various engineering disciplines.

This course is meant to provide an introduction to humanitarian engineering via a hands-on experience. It serves as preparation for ENGR 5050 below, but any student going through the First Year Engineering also satisfies such a prerequisite.

Building upon the First Year Engineering Program, we have a general 3-credit course on humanitarian engineering that serves a number of purposes: (i) it can include students at any level, from freshmen to $\mathrm{PhD}$, (ii) it is suitable for any engineering major, (iii) it can serve as the "core course" for the Humanitarian Engineering Minor (see below), and (iv) yet it still has significant and relevant technical content. Most engineering departments accept this course as a technical elective.

ENGR 5050 Humanitarian Engineering: Poverty, development, culture; social justice; development strategies; engineering for community development. Matlab/Simulink simulations for modeling and analysis of each of these topics, appropriate technology design challenge, and book report. The textbook for the course [1] is available for a free download. 
Technical content includes modeling, dynamics, and computational analysis. This technical content was chosen as it can be assumed that all engineering majors have had calculus and experience with Matlab. The course is highly multidisciplinary across the engineering disciplines, incorporates the social sciences, social justice, education, and business (via the treatment of social business). The course lectures are recorded and posted on-line for free download.

A course that can either precede or follow ENGR 5050 (best if it follows it) is ECE 5194.06 below. This 3-credit course goes into all the details of the technical topics covered in ENGR 5050, "quantitative development economics from an engineering perspective," and introduces a number of new topics also. It is designed for juniors, seniors, or graduate students.

ECE 5194.06 Computational Humanitarianism: Simulation and computational analysis of financial management of a poor household; wealth distribution policies in a community; democracy in a community; nonlinear dynamics of economic growth (e.g., poverty traps) and technology diffusion; cooperative pricing for resource maintenance in a community, nonlinear dynamics of development. Matlab/Simulink, Monte Carlo simulations, and statistical analysis.

We have a variety of engineering service-learning courses that are used for pre-travel and pre-field work preparation. Such courses are generally required of all students that work on an international project. It is desirable that a student has ENGR 5050 before they take a servicelearning course. Sometimes, a service-learning course plus fieldwork is accepted as satisfying a department's capstone design requirement. The number of credit hours for these course is variable, but most often three.

ENGR 4692 Engineering Service-Learning: There are multiple sections of this course used for trip preparation for various international service trips (e.g., for Honduras, Guatemala, Haiti, etc.). Typical coverage includes technical design for context, which often means design of appropriate technologies, teamwork, and trip preparation (e.g., study of culture).

In many cases, students use humanitarian engineering as the basis for their capstone design project in a capstone design course in the department of their discipline or in our college capstone design education program. These capstone design projects often involve travel and field work, but for some students, they do not. Capstone design is either in one or two semesters, providing 3-6 credit hours.

Capstone Design Courses: Departments require either a one- or two-semester capstone design experience, and these are used in several cases as preparation for an international project.

For international projects, guided by faculty or staff, students do fieldwork in humanitarian engineering. In most cases, this is credit-bearing via "study abroad" through our Office of International Affairs (OIA).

Study Abroad: Humanitarian Engineering Fieldwork: Most of our international programs give academic credit for the actual fieldwork in engineering via "study abroad credit." 
There are several other ways that students can get academic credit for their learning and project work in humanitarian engineering: (i) Undergraduate Independent Study and Undergraduate Research: These are used to give academic credit to some students who are doing engineering work for community service, either locally or internationally (e.g., students not needing, or ready for, capstone design credit); such credit has been used in the past for, for instance, a local service project involving database design, and for international service for technical design and study abroad (e.g., in Honduras); and (ii) Undergraduate Honors Thesis: For an approved research program, students can do an undergraduate honors thesis and thereby obtain an "honors with distinction" on their diploma. For instance, a current student is designing a software system for a local social service provider for his honors thesis.

\section{Humanitarian Engineering Minor:}

Our Humanitarian Engineering Minor started in Aug. 2014 and is available to all majors in the College of Engineering, and at times to other academic majors provided they can meet the requirements. The minor is quite flexible and, if a student's course schedule is designed properly, will not extend the time to graduate. The requirements for the Humanitarian Engineering Minor are:

TABLE 1

HUMANITARIAN ENGINEERING MINOR

\begin{tabular}{|l|l|l|}
\hline \multicolumn{1}{|c|}{ Category } & \multicolumn{1}{c|}{ Classes/Service } & \multicolumn{1}{c|}{ Credits } \\
\hline Core course & ENGR 5050 Humanitarian Engineering & 3 credits \\
\hline Human welfare & $\begin{array}{l}\text { Wide range of courses (e.g., development } \\
\text { studies, social work, economics, human } \\
\text { disabilities) }\end{array}$ & 6 credits \\
\hline Service & $\begin{array}{l}\text { Preparation course (e.g., service-learning or } \\
\text { capstone design), study abroad/fieldwork, } \\
\text { portfolio for documenting service }\end{array}$ & 6 credits \\
\hline Total & \multicolumn{1}{|c|}{15 credits } \\
\hline
\end{tabular}

The above requirements were used to make it relatively easy for a student to complete this minor. Students taking the core course can typically get credit for a technical elective, which is something they need anyway. The courses on human welfare can be double-counted with typical "general education" requirements in engineering. The service component can be satisfied by appropriate capstone design participation. Local or international service is accepted for the service category.

\section{MS Thesis Projects:}

Sometimes, our humanitarian engineering projects have required the involvement of more advanced students. Along these lines, Masters Thesis projects have included the following: (i) Low cost palm oil press for Africa; (ii) Wind mill project; (iii) Modeling and simulation of a food pantry to improve logistics; and (iv) Feedback control for financial management of poor 
households. Some of these have involved fieldwork. We also have quite a few advanced research projects in progress that involve MS and $\mathrm{PhD}$ students being supervised by faculty (see our web site).

\section{Lessons Learned from Curricular Program:}

We have learned a number of lessons from running our above curricular program. First, we consider the various advantages and disadvantages of using a service-learning class vs. capstone design vs. a combined approach to international service trip pre/post-travel work:

TABLE 2

LESSONS LEARNED FROM CURRICULAR PROGRAM

\begin{tabular}{|c|c|c|c|}
\hline \multicolumn{2}{|c|}{ Service-Learning course ( 3 credits) } & \multicolumn{2}{|c|}{ Capstone Design class(es) (3-6 credits) } \\
\hline Advantages & Disadvantages & Advantages & Disadvantages \\
\hline $\begin{array}{l}\text { May count as a } \\
\text { technical elective }\end{array}$ & $\begin{array}{l}\text { Generally, does not } \\
\text { count for capstone } \\
\text { design requirement, } \\
\text { but can on special } \\
\text { request }\end{array}$ & $\begin{array}{l}\text { Counts for degree } \\
\text { credit }\end{array}$ & $\begin{array}{l}\text { For a } \\
\text { multidisciplinary } \\
\text { team, difficult to } \\
\text { manage differing } \\
\text { departmental } \\
\text { requirements }\end{array}$ \\
\hline \multirow[t]{2}{*}{$\begin{array}{l}\text { May count for } \\
\text { academic credit for } \\
\text { students not } \\
\text { needing, or ready } \\
\text { for, capstone design }\end{array}$} & $\begin{array}{l}\text { May not count in } \\
\text { faculty loading } \\
\text { credit if not run out } \\
\text { of their department }\end{array}$ & $\begin{array}{l}\text { Counts for faculty } \\
\text { loading credit if run } \\
\text { out of their } \\
\text { department }\end{array}$ & $\begin{array}{l}\text { Student ready for } \\
\text { service may not be } \\
\text { ready for capstone } \\
\text { design }\end{array}$ \\
\hline & $\begin{array}{l}\text { Usually one } \\
\text { semester, and in } \\
\text { some cases not } \\
\text { sufficient } \\
\text { preparation } \\
\end{array}$ & $\begin{array}{l}\text { If two-semester } \\
\text { version, usually } \\
\text { sufficient } \\
\text { preparation }\end{array}$ & \\
\hline \multicolumn{4}{|c|}{ Service Learning (SL) course and Capstone Design (CD) classes } \\
\hline \multicolumn{2}{|c|}{ SL course before CD course } & \multicolumn{2}{|c|}{ Simultaneous SL/CD classes } \\
\hline \multicolumn{2}{|c|}{$\begin{array}{l}\text { Sometimes students take a service-learning } \\
\text { course (that may count as a technical } \\
\text { elective) and project trip before capstone } \\
\text { design; this tends to nicely focus their } \\
\text { design course }\end{array}$} & \multicolumn{2}{|c|}{$\begin{array}{l}\text { Sometimes capstone design is taken } \\
\text { simultaneously with a service-learning } \\
\text { course that has fieldwork }\end{array}$} \\
\hline
\end{tabular}

We have also learned that it is important to exploit other approaches to giving course credit. There have been times when giving independent study or undergraduate research credit has fit student course schedules and service activities very well (e.g., when they are not ready for capstone design, as a precursor to capstone design, or to provide credit for students doing a lot of engineering service). The honors research and thesis approach has been appropriate for individuals (not on teams) doing significant service. 
We have also identified a number of curricular needs. First, there is significant student interest in a general course on engineering for sustainability and the environment, one that any major in engineering could take. It would also be useful to have a course on social entrepreneurship for appropriate technology and a service-learning course for projects in Central Ohio. Recently, a new faculty has arrived in civil engineering and is developing a course on sustainable community development. Moreover, there are plans to develop an advanced course on appropriate technology for juniors, seniors, and graduate students.

Through our experiences above with MS thesis projects, and the level of graduate student interest in our courses (e.g., ENGR 5050 and ECE 5194.06), it has become clear that we need to consider adding an MS program in humanitarian engineering. This is likely to be a minor for an existing disciplinary MS degree, certificate, specialization, dual-MS, or the like. In any case, we intend for the MS student to get a degree in a traditional major, but have some type of emphasis in humanitarian engineering. We are exploring how the MS program can incorporate other disciplines like social work, business, policy, anthropology, international studies, etc.

\section{Extracurricular, Co-Curricular, and Local Service Activities}

We have significant learning and service project activities that occur outside the classroom, or in fieldwork for study abroad as outlined above. For instance, our service-oriented engineering student organizations engage in significant local and international service. Moreover, our Humanitarian Engineering Scholars program is a "living-learning community" built around a humanitarian engineering theme.

\section{Engineering Student Organizations:}

There are seven College of Engineering student organizations that have humanitarian engineering activities. Each organization has a faculty advisor, meetings, a web site, and most have both local and international projects, which will be discussed below. The organization's main features are:

1. Engineers for Community Service (ECOS): This group formed in 2004, is inclusive of all engineering majors, has won a number of awards at OSU for its work, and ran a regional conference in 2008.

2. Engineers Without Borders (EWB): This chapter of the national organization formed in 2009 at OSU and is centered in civil engineering. EWB works closely with the Central Ohio chapter of professional engineers in EWB, and tends to focus on civil engineeringbased community service projects.

3. Engineers for a Sustainable World (ESW): This chapter of the national organization formed in 2010 at OSU and focuses on sustainability and green engineering, and in 2014 they ran a regional conference.

4. Solar Education and Outreach (SEO): This group formed in 2010, focuses on education for, and installation of, solar systems for communities. It won an OSU award in 2013 for its work. 
5. Design Building Institute of America-OSU (DBIA-OSU): This organization focuses on design and construction services in shaping the built environment and has focused on design for disadvantaged neighborhoods in Columbus, Ohio.

6. SERVitecture: This organization focuses on topics related to the fields of architecture, landscape architecture, and city and regional planning, and has activities that include week-long service trips, design-build projects, and campus-based events.

7. Ecological Engineering Society (EES): This group is based in the Dept. Food, Agriculture, Biological Eng. and focuses on sustainability and the environment.

Each organization conducts various short term and ongoing diversely focused projects that give students an opportunity to engage in an activity that meets their particular interests, skills and passions. Students are encouraged to take on leadership roles in existing projects as well as create new projects to meet community needs. Though the size of these organizations is not precisely known, many of our students are involved in at least one of these organizations.

\section{Lessons Learned from Student Organizations:}

As you can see from the above dates, we have about 10 years of experience in working with student organizations that are service-oriented. We highly value these groups, view them as an integral part of our overall program, and indeed see them as a fundamental driver of our success. The particular lessons learned for student organizations include:

1. Higher number of organizations promotes ownership and activity: In the last 10 years quite a few new humanitarian engineering student organizations have been formed. At OSU it is relatively easy to form a student organization. It happens from the grassroots level with students organizing into a sufficient size group, finding a faculty or staff to be the advisor, and making a proposal to the university. We have found that organization formation gives "ownership" to a student group with like interests (e.g. a technology like solar systems or a major like civil engineering) and thereby generates lots of involvement, enthusiasm, and service activity.

2. A high number and diversity of service project types promotes student involvement: The high number of student organizations has naturally generated a diversity of project types, but there have also been efforts to diversify the project portfolio within the organizations. We find that if you have a low number of projects, then there are some students who do not have the expertise or interest in these and they are "lost" to the student organization. Project diversity promotes student involvement.

3. Independence promotes student leadership and teamwork: One of the most valuable aspects is for the students to have practice at leadership and teamwork on projects and if the advisor gently guides the group, appropriately stepping back and letting them work, students often produce great results. This leads students to learn "how to get it done" which is a skill lacking in many new graduates without such practical real world experience.

4. Experience in project management is important: One challenge students have is that of project management with real people, an authentic engineering problem, and most often a real client, and this gives them valuable experiential learning. 
5. Promotion of other humanitarian engineering programs: While often our student groups are heavily involved in our domestic and international service projects, and help promote these, they also (via word-of-mouth or e-distribution) help promote our other activities (e.g., seminars and classes).

6. Fosters a spirit of volunteerism: There are a significant number of our students who do service without academic credit, both via the student organizations or the HES program. These groups provide the opportunities, and students take them.

7. Provide a social component to our program: Student organizations and the HES run a variety of social activities that are important to team-building in our program.

\section{Student Organizations' Projects:}

Our primary location for domestic humanitarian engineering projects is Franklin County, where Columbus, Ohio and OSU main campus are located. Our proximity to urban poverty and its challenges facilitate building relationships, understanding context, and minimizing student transportation challenges. Local service is a great introduction to humanitarian engineering, even though there can be significant language and cultural differences (e.g., in Columbus, with its large Somali or significant Hispanic populations). It provides authentic problems and real clients to satisfy. It also appeals to some of our students who are more concerned about addressing local challenges rather than international development.

A sampling of the local projects based in our student organizations are:

1. K-12 Outreach for education on solar systems

2. Friends of the Lower Olentangy Water projects (environmental projects)

3. Computer education for senior citizens

4. Wheelchair ramp design and installation for disadvantaged disabled persons

5. Downhill derby car design for disadvantaged children

6. Rain garden design and installation

7. Web page design for an international NGO based in Columbus

8. Phone-A-Buckeye Science, Technology, Engineering and Mathematics (STEM) question hotline for tutoring students in grades 9-12 in Central Ohio (via Facebook and the phone)

9. AID India project that focuses on app design via work with an NGO in India that targets STEM education for Indian school children

10. Community Technology Clinic: Web page design for a local food pantry, database design for a social service-provider weekend service event for disadvantaged senior citizens, work with the Open Shelter to design cooking and lighting strategies for the homeless, MS project on logistics for a food pantry mentioned above, undergraduate honors research and thesis on software design for a social-service provider mentioned above. This project involves a collaborator from the College of Social Work.

\section{Lessons Learned from Local Service Projects:}

Local service project provide easily-accessible humanitarian engineering projects, fieldwork, and work with real clients. While we hope to expand our local service program, over the past 10 years we have learned a number of lessons from our local service activities: 
1. Service-providers are key partners: We like to "serve those who serve" (i.e., social service providers) as they are professionals and know needs in a community. Examples of this are our work with the director of the Open Shelter, the director of Worthington Food Pantry, Mid-Ohio Food Bank and the staff at Catholic Social Services.

2. Local service can have global impact: In some cases, while service is delivered via local work, it has global impact. The line between what is domestic and international is blurred by the possibility to work remotely via the internet. For instance, all the work on the ECOS "AID India" project is being done at OSU by 8 students, but the prime target for the work is Indian schoolchildren.

3. Service projects for capstone design: Several departments in the College of Engineering have expressed interest in obtaining more quality capstone design challenges for their students via local service projects since such projects give authentic technical challenges and a real client (or clients) to satisfy. We currently have a few such projects in progress.

\section{Humanitarian Engineering Scholars:}

The Humanitarian Engineering Scholars (HES) Program at OSU is a "living-learning community" co-curricular program that currently has approximately 270 student members. It features:

1. A two-year program, wherein students live in a dorm together their first year;

2. HES "events" that include having speakers on a range of topics, including humanitarian engineering;

3. A requirement of $10 \mathrm{hrs}$. service per semester which most often has been fulfilled via local community service; and

4. With respect to academics, there are special versions of first year engineering classes for HES, including a class on appropriate technology (see more discussion below).

Students are expected to connect their HES program with the humanitarian engineering activities described in this paper. There is a new project called Colaboración Guatemala that is an engineering service trip.

The main lessons learned from this program are that: (i) the HES program is successful at attracting top quality students (better than the average admitted student) due to the humanitarian engineering focus; (ii) it is useful to engage students very early in the academic career in humanitarian engineering to help set their focus and meet their educational aspirations; and (iii) it helps promote our college-wide humanitarian engineering activities.

\section{International Projects}

The key to our success for our international projects is our partners who are living in country. Several of our partners are OSU Alumni and this makes them particularly willing to help with our educational mission, and help us work with the community they live in or near. Before we take students on an international trip, one or two faculty or staff travel to the site to assess, with the help of a partner, the suitability of the site for student projects, and begin to build relationships in the community. Our criteria for site suitability include adequate: (i) security, (ii) 
health, (iii) food/water, (iv) housing, and (v) transportation. Another consideration is the availability of bilingual partners on the ground. Our Office of International Affairs helps assess security and provides health insurance to travelers for a small cost. Provided the site is suitable, we also seek to start to define engineering challenges, though needs assessments are typically also done on trips with students. Then, we return to OSU to set up a preparation course (servicelearning or capstone design) and arrange with our Office of International Affairs to set up a Study Abroad course.

We now have a number of international sites that we collaborate with on humanitarian engineering projects. The active projects are briefly outlined next (for more information, please see our web site provided earlier):

\section{Colombia:}

1. Project Managers: Kevin Passino and Betty Lise Anderson

2. Location: Bogotá and Pasto

3. Partners: Andrés Pantoja (professor at Universidad de Nariño), Nicanor Quijano (professor at Universidad de los Andes), Universitaria Minuto de Dios, Pequeños Cientifícos, Liceo (K-12 disadvantaged school attached to Universidad de Nariño), and two professors from the OSU College of Education and Human Ecology.

4. Project Overview: Design and implementation of low cost engineering laboratory experiments for disadvantaged universities and for K-12 STEM education, experiments focused on representing local social and industrial problems.

\section{Dominican Republic:}

1. Project Managers: Gajan Sivandran, EWB, and local professional chapter

2. Location: Esfuerzo de Paraiso (outside Santo Domingo)

3. Partner: Community of Esfuerzo Paraiso

4. Project Overview: The objective of the project is to mitigate flooding and exposure to contaminated water.

\section{Ghana I:}

1. Project Managers: Joe Campbell and Kim Burton

2. Location: Offinso North District (ND)

3. Partners: Offinso North District Assembly (ONDA) and Kwame Nkrumah University of Science and Technology

4. Project Overview: The purpose of the Ghana Sustainable Change (GSC) program is to improve housing, site development, community planning, renewable energy, public health, water, sanitation, agriculture, education, governance, economic development, and public outreach and engagement.

\section{Ghana II:}

1. Project Manager: Roger Dzwonczyk

2. Location: Offinso North District

3. Partner: Offinso North District Assembly, Kwame Nkrumah University of Science and Technology (in-country academic), OSU Knowlton School of Architecture City and Regional Planning

4. Project Overview: In this new program students collaborate with our partners to bring useful, sustainable technologies to the Ghanaian people. 


\section{Guatemala:}

1. Project Managers: Kevin Passino and Rachel Tuttle

2. Location: Panajachel, Lake Atitlán

3. Partner: NGO, Mayan Families

4. Project Overview: Engineering projects for Mayan communities, including cook stoves, water filtration, solar-powered light, and K-12 STEM education.

\section{Haiti:}

1. Project Manager: Roger Dzwonczyk

2. Location: Les Cayes, Haiti

3. Partner: Torch of Hope (in-country faith based NGO), OSU Haiti Empowerment Project (OSU academic), Universite Lumiere (in-country academic), American University of the Caribbean (anticipated in-country academic)

4. Project Overview: Through SEO, students assess needs, and then research, design, develop, prototype and plan various solar projects to meet these needs.

\section{Honduras/Choluteca I:}

1. Project Manager: Roger Dzwonczyk

2. Location: Choluteca, Honduras

3. Partner: World Gospel Mission (in-country faith-based NGO), numerous interdisciplinary partners (OSU academic, US academic, business and NGO)

4. Project Overview: Students collaborate with our established in-country partner to bring useful, sustainable technologies to the people of Honduras (e.g., sustainable/renewable energy, water purification, aquaponics, healthcare etc.).

\section{Honduras/Choluteca II:}

1. Project Manager: Howard Greene

2. Location: Choluteca, Honduras

3. Partner: World Gospel Mission

4. Program Overview: This involves multi-year projects in aquaponics and sustainable housing where the overall project aim is a complete solution with the appropriate business, training, and maintenance support elements in place for long-term sustainability and replicability.

\section{Honduras/Montaña de Luz:}

1. Project Manager: John Merrill and Edgar Casale

2. Location: Montaña de Luz HIV/AIDS orphanage (MdL)

3. Partner: Montaña de Luz, NGO based in Worthington Ohio

4. Project Overview: This project, initiated through ECOS, has addressed a wide range of needs for the orphanage including computer installation and education, electricity, alternative energy (e.g., biodigester and wind-based), aquaponics, tilapia pond, irrigation, water quality, and others.

We have a number of other programs including two programs in South Africa, past trips to El Salvador and another location in Guatemala, and Lisa Fiorentini manages a program where a 
"basic utility vehicle," a small truck to transport water, is being built and entered in a national competition run by the Inst. of Affordable Transportation.

\section{Lessons Learned from International Projects:}

After 10 years of experience in running international service projects with student teams, work in 13 locations that include Latin America, the Caribbean, and Africa, collaborations with orphanages, local governments, healthcare facilities, communities, NGOs, and foreign universities, and development and deployment of a wide array of humanitarian technologies, we have learned a number of lessons:

1. An in-country partner is crucial: Having a good partner, such as an OSU Alum, is crucial for the long-term success of the project. It helps with initial site assessment immensely, and with the on-going execution of a project. The partner can typically give advice on needs, help build relationships with the right people in a community, warn of any tricky social problems, and help with trip logistics (hotel, food, and transportation). It can be difficult to first establish a partnership and it always requires travel and spending time together to build a relationship. Moreover, it can be difficult to maintain a relationship when there are only relatively infrequent visits (e.g., in some cases once a year), in spite of possible internet communications.

2. Relationships are important: While the relationship with the partner is crucial to project success, the relationship with other community members is also very important. We seek community member involvement at every step of the process, from needs assessment, to design, deployment, performance assessment, and maintenance. Community "buy-in" is crucial to long-term success of a development effort. Building relationships with a community shows respect; nothing gets done except "on the back of relationships."

3. Onsite project assessment is a key to a successful project outcome: Onsite assessments, that are done in close collaboration with the community, provide an opportunity to develop relationships with the end users of the project, get a clear understanding of the problem(s) to be undertaken, gather metrics and identify local resources. In this way a job proposal and scope of work can be formulated that is mutually agreeable among all stakeholders in the work.

4. Project travel timing and finances: International travel typically occurs outside the academic calendar. Hence, we run project trips in Spring Break (10 day trips), what we call "May term" (at OSU, basically the month of May) and these can be 14 or more day trips, summer trips (typically 10 days), and January before classes start (10 day trip). Different student groups are attracted to different travel times, but many like the Spring Break or May term time slots, and these two work well in terms of course preparation timing. Some of our trips only have once-a-year travel, while a few have project trips more frequently. Maintaining project continuity can be difficult if there is only one travel period per year. Scheduling a trip is difficult as some of these time slots do not work well with community partners, e.g., if they occur during rainy season. Choice of travel time and whether to run the trip as a Study Abroad program are also affected by finances: (i) the College of Engineering gives each student doing an approved Study Abroad trip a stipend, and these Study Abroad experiences are typically in Spring Break or May term; and (ii) OSU, over the past few years, has given 3 credits at no cost to students in May 
term who were enrolled full time during the previous Spring Semester (this policy, however, may not continue).

5. Course preparation is important: While the bulk of course preparation is on technical matters and design, issues like culture, history, or traditions in the country to be travelled to are also discussed. The team-building that occurs in our courses, and sometimes at pretravel social events, is probably the most important outcome that prepares the students to work effectively at an international site.

6. Multidisciplinarity is pervasive and valuable: Our project teams are almost always composed of students of a variety of engineering and, at times, non-engineering (e.g., biology, business, agriculture) majors, both in their preparation courses and for fieldwork. We find this highly desirable as it promotes significant learning for the students, provides them the opportunity to confront team/project management challenges with a diverse group, and helps them understand the value of different engineering disciplines. In the past we have also involved business students in a project. At the present time, we are working to involve students with other majors, for example, in the social sciences.

7. Engage the local diaspora: The local diaspora can help in course preparation (e.g., the coverage of culture, economics, and politics), identification/evaluation of candidate projects, and provide travel advice. Approaches like this have been used for our Ghana, Colombia, and Honduras programs.

8. Communication is crucial for the success of the programs and projects: Dialog between the program manager and the in-country partner, i.e. the "boots on the ground", must continue throughout the year regarding completed projects, multiyear projects and proposed new projects. Often there are several three or four member student teams in the program, each working on a separate project. We have found that, in some cases, assigning one student from each team as chief communications officer is an effective way for the teams to stay in contact with the in-country partner without overwhelming the partner with questions about the project.

9. Find creative communication strategies: Email and phone calls are not always feasible and, in some cases, are not the ideal forms of communication. Newer approaches, including What'sApp, Facebook, and Skype, which require internet access but not extensive data usage, can be cheaper and more reliable forms of communication (e.g., with West Africa). These forms of communication are best for maintaining good personal relationships but obviously are limited for sharing documents.

10. Value of getting out of the US: Many of our students have said that they learned a lot simply by traveling outside the US, and in particular to the developing world. They see how most people in the world live, experience a different culture, and are challenged because they are taken outside their "comfort zone" (e.g., foreign-language immersion, different food/drink, and cold showers!).

\section{Meetings and Coordination}

Since Jan. 2013 there has been in the OSU College of Engineering a "Humanitarian Engineering Advisory Committee" (comprised of about 15 faculty, staff, and students) that discusses and coordinates issues related to Humanitarian Engineering for the College. Issues addressed include 
curricula, project best practices, seminar series, and funding. As well, at each meeting, either a student organization or faculty member is invited to present the results of a recent trip or project. Recently, a web site was established for running OSU Humanitarian Engineering e-Seminars. Traditional seminars are given, recorded, and posted for persons not able to attend. Also, our technology allows for international partners to give seminars remotely that can also be recorded and posted.

At the present time, a "virtual community of practice" on humanitarian engineering called the "Scholarship in Engineering for Social Justice: A Practitioner's Forum," is in operation. This involves engineers and professors from around the world interested in university education and projects for humanitarian engineering. We use "Adobe Connect" to implement multi-user video/audio teleconferencing, a "webinar." A repository of videos of the sessions (and documents) is held at the above web site. This e-forum is meant to reach out far beyond the OSU HE e-Seminars approach above.

\section{Humanitarian Engineering Center}

All our humanitarian engineering activities have recently been consolidated under a "Center" and in this section its formation, success drivers, and value are briefly discussed.

\section{Center Formation and Overview:}

In Autumn 2013 a proposal was made to the College of Engineering to establish a new center in the area of humanitarian engineering. This involved having a group write a proposal to College leadership, providing a presentation on the idea, and presenting the proposal to the "Executive Committee" (the department chairs). In June 2014 the proposal was accepted (and funded) so that all the above humanitarian engineering activities were consolidated under the umbrella of a "Humanitarian Engineering Center" (HEC) as shown in Figure 2.

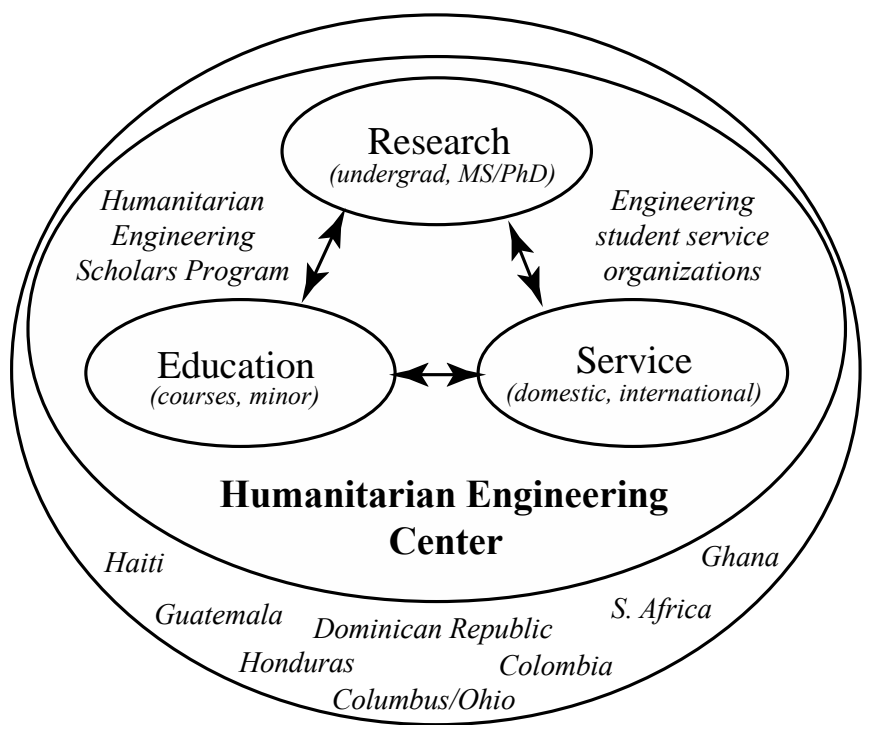

FIGURE 2

HumANiTARIAN ENGINEERING CENTER 
In Figure 2 we view the oval representing the Center to be embedded in the communities listed in the outer oval (the world) via our collaborative work with faculty, staff, students, and community members. At OSU the Center activities are broken into the three main university mission objectives of teaching (education), research, and service that were outlined above. It also includes the extracurricular activities of student organizations and the HES program. Our coordination is achieved via the Humanitarian Engineering Advisory Committee, and our seminars reach out to educate students and share experiences.

\section{Success Drivers That Led to Center Formation:}

If we had not achieved significant success, we would never have proposed a Center, let alone gotten it approved. What drove this success? The following were the key factors:

1. Student interest: Experience has shown us that one of the biggest drivers for success in the last 10 years is the very strong student interest and involvement. Indeed, this is part of a larger national trend in the US as research has shown that the generation of "Millennials" (or "Generation Y", generally defined as persons born in the US between the early 1980s and the early 2000s): has $63 \%$ who have volunteered for a nonprofit and $75 \%$ who have given to a nonprofit, unusually high percentages compared to past generations [2].

2. Faculty/staff involvement: There have been a significant number of faculty and staff willing to serve as advisors for student organizations, to teach courses, to assess and choose service sites, and especially to lead student project trips abroad.

3. University support: We have gotten good support from departments, the College of Engineering, and the university (e.g., the Office of International Affairs and the Service Learning Initiative) for our activities.

4. Partnerships: We have many excellent partnerships and input from the communities we work with, including those who are OSU Alumni living in developing countries/communities where we work. Also, we have excellent partners in other parts of OSU including social work, business, education, and development studies.

5. Financial support: We have had financial support from foundations and other sponsors.

Many of the above drivers are strengthened by a key advantage we have at OSU: size. We have about 55,000 students enrolled at the OSU main campus in Columbus. Per our College of Engineering annual statistical report for 2013 [3], we had 8621 undergraduates in engineering, 1861 graduate students, 297 tenure-track faculty, 147 non-tenure track faculty/instructors, and 359 staff. This provides a large pool of people who are interested in, and enthusiastic about, humanitarian engineering.

\section{Center Value:}

While we are too newly formed to have many "lessons learned," the value of having formed the Center is becoming clearer. First, it has provided some budget from the College of Engineering. It has given good press to our program across the College of Engineering. It is helping with visibility and outreach to other units at OSU. It is strengthening our "pitch" to potential donors 
and external funding agencies. Finally, our people are working together for vision and objectives formation for the Center and this is forcing us to communicate and learn from each other.

\section{Conclusions: General Lessons Learned}

We have two overarching lessons learned that form the conclusions for this paper. The first highlights the ways that our activities in humanitarian engineering have demanded changes to engineering education. The second is the recognition of the gender diversity that we find in humanitarian engineering that we hope will improve recruitment and retention of women in engineering.

\section{Expanding and Enriching Engineering Education:}

In addition to confirming the value of experiential engineering education (e.g. via authentic design challenges and field work in engineering), we have learned the following lessons on expanding and enriching engineering education:

1. Social sciences as a new foundation for engineering: Traditionally, sciences used by engineers include physics, chemistry, and biology. Humanitarian engineering also demands the inclusion of topics from the social sciences such as social work, sociology, anthropology, economics, political science, and sometimes psychology. Faculty in engineering typically only have cursory knowledge of at best a few of these areas, yet in the university it is social work that best understands the problem of poverty and clearly development economics is a key field. There is then a significant challenge to develop and teach courses supporting humanitarian engineering where such topics are integral parts of the material. This is particularly challenging as social science colleagues do not always know how to help as the challenge is the integration of social sciences and engineering, and they typically do not know any engineering. On the other hand, it is difficult for engineers to learn areas in the social sciences to promote integration. Another difficulty in communicating with social scientists is that if they use mathematics, it is typically statistics, game theory, network theory, or multiagent systems simulation at times (e.g., via Netlogo). Engineers use all these and also use calculus, differential equations, numerical/computational analysis, and dynamical systems; however, these topics are not generally understood by social scientists. This makes our work difficult to understand for them, and thereby barriers exist to effective collaboration.

2. Integrating engineering and business: The area of social entrepreneurship for appropriate technology demands an integrated approach to classroom instruction and multidisciplinary approach to service teams. There are challenges to collaborating with business, but engineering and business are natural partners (e.g., many of our students later go get an MBA or become business people rather than engineering practitioners).

3. Pervasively multidisciplinary: "Multidisciplinary" takes on many meanings in the university; however, traditionally it meant collaboration between at least two disciplines in engineering. Per the above discussion there needs to be a significant expansion of such a view. We need social scientists in our classrooms, on our capstone design teams, in working hand-in-hand on service projects, both local and global. There is an opportunity 
to enhance the disciplinary diversity in our programs due to the demands of humanitarian engineering.

4. Solving problems: Often our engineering students think about solving problems for people like themselves - which are often first world problems. It is especially educational that students are able to see a new perspective on the world and the problems that face most of its population. With a new set of constraints and requirements, students are required to solve problems using their engineering knowledge and creativity coupled with in-country partners. Furthermore, our students are faced with figuring out "how to get the job done," which is something that the typical classroom is unable to simulate (i.e. real world scenarios).

\section{Diversity:}

Research by the National Research Council/NAE/NAS has shown that girls/women often pick their career field based on how much they think that they will be able to impact humans and society [4]. Anecdotal evidence, from the above OSU engineering student organizations, has shown that women participate at higher rates than do men in our humanitarian activities (especially in leadership roles), even though there are fewer women than men enrolled in the College of Engineering. Women students are disproportionately represented on humanitarian engineering service learning trips. Over the time range 2005-2014 there were 198 participants in international engineering service project trips to the three Honduras locations (see above), of which about one half have been female (in 2012 the undergraduate engineering student population was $19 \%$ female). These percentages are virtually identical to ones found nationwide for chapters of EWB and ESW [5]. Next, in the class ENGR 5050 Humanitarian Engineering offered Spring 2014, as of 11/16/13 there were 35 students enrolled (9 graduate students and 26 undergraduates) 16 are women and 19 are men, or $46 \%$ women, again consistent with the above findings.

Along these lines, it is interesting to note that of the persons involved (to varying degrees) in our current humanitarian engineering activities, there are 18 men (engineering), 3 men (architecture), 6 women (engineering) and 3 women (architecture) classified as "faculty" (tenure-track, clinical, etc.). Hence, there are 33\% women faculty (engineering) and 50\% women faculty (architecture) involved in humanitarian engineering. Considering that the percentage of female faculty in the College of Engineering in 2013 was $18 \%$ (engineering) and $43 \%$ (architecture), women faculty are disproportionately represented in humanitarian engineering, consistent with the National Research Council/NAE/NAS findings [4].

Hence, these data suggest that prospective women engineering students and faculty are likely to find the availability of the HEC with its research, educational, and service project opportunities attractive, increasing the likelihood that they are recruited to OSU and retained in engineering (and it is a recruitment/retention approach that differentially affects women over men).

Next, several researchers/practitioners in humanitarian engineering (including some minorities) believe that a program in humanitarian engineering would help recruit and retain minorities in engineering; however, this relationship has not yet been established through quantitative research to the authors' knowledge. We have, however, seen anecdotal evidence of disproportionate minority participation (e.g., in the ENGR 5050 course). 


\section{REFERENCES}

[1] Kevin M. Passino, Humanitarian Engineering: Creating Technologies That Help People, Edition 1, Bede Pub., Columbus, OH, 2014 (available for free electronic download).

[2] The Millennial Impact Report 2012, by Achieve and the Case Foundation, 2012.

[3] The Ohio State University College of Engineering Annual Statistical Report, 2013.

[4] To Recruit and Advance: Women Students and Faculty in Science and Engineering, National Research Council, National Academy of Sciences Press, 2006.

[5] Thomas H. Colledge, ed., Convergence: Philosophies and Pedagogies for Developing the Next Generation of Humanitarian Engineers and Social Entrepreneurs, Int. Journal of Service-Learning in Engineering: Humanitarian Engineering and Social Entrepreneurship, 2012. 